\title{
WHAT MAKES A LAW "ISLAMIC"? A PRELIMINARY STUDY ON THE ISLAMICITY OF LAWS IN MALAYSIA
}

\author{
Ramizah Wan Muhammad*
}

\begin{abstract}
There exists a good deal of misunderstanding regarding laws in general. Some laws are categorised as civil or common laws even though their contents are Islamic while others are labelled Islamic but they fail to meet the standards required by Islamic law. This article discusses the characteristics, which make a law, "Islamic". Based on a content analysis of the revealed sources, the opinion of the majority of Muslim scholars, and the relevant court cases, this study argues that a law does not become Islamic by merely claiming it to have been derived from or somehow related to the divine revelation. It is true that for any law to be Islamic, it must indeed be based upon the divine revelation, and supported by Muslim jurists. Nevertheless, it must also simultaneously be promoting justice for everyone, irrespective of race, religion, gender, social, economic or political status. The law must also be of benefit to all mankind and not only to the Muslims. Finally, the law must fulfil the requirements of Maqāșid al-sharī'ah (objectives of the law). Judged as such, most of the Malaysian laws may be considered to be Islamic, by nature. These aspects have not been given due attention by many scholars, which leads either to the condemnation of all laws in Malaysia as secular or as un-Islamic. This fact alone justifies the need for a study to provide guidelines to judge the Islamicity of a certain law, which is done herein.
\end{abstract}

Keywords: Islamic law, Maqāṣid al-Sharī'ah, ta'zīr, Human Rights

\footnotetext{
* Associate Professor, Department of Islamic Law, Ahmad Ibrahim Kulliyyah of Laws, International Islamic University of Malaysia. Email: ramizah@iium.edu.my
} 


\title{
APA YANG MENJADIKAN SESUATU UNDANG-UNDANG ITU "ISLAMIK"? SUATU KAJIAN AWAL TENTANG KEISLAMAN UNDANG-UNDANG DI MALAYSIA
}

\begin{abstract}
ABSTRAK
Terdapat banyak salah faham mengenai undang-undang secara amnya. Terdapat sesetengah dikategorikan sebagai undang-undang sivil atau undang-undang am walaupun mengandungi isi kandung yang berbentuk Islamik. Manakala terdapat undang-undang yang dilabel sebagai Islamik, tetapi pada hakikatnya tidak memenuhi standard yang ditetapkan oleh Islam. Makalah ini membincangkan ciri-ciri yang membolehkan membuatkan sesuatu undang-undang itu sebagai "Islamik". Melalui kaedah analisis kandungan yang dilakukan keatas sumber-sumber wahyu, pendapat cendikiawan Islam, kes-kes mahkamah yang berkaitan, kajian ini menghujahkan bahawa sesuatu undang-undnag itu tidak menjadi "Islamik" hanya dengan kenyataan bahawa isnya didasari ataupun berkait dengan wahyu Ilahi. Sememangnya untuk mana-mana undang-undang di anggap sebagai Islamik, ianya harus selari dengan ajaran yang disampaikan Islam. Walaubagaimanapun, ini tidak mencukupi. Selain dari itu, undang-undang tersebut seharusnya turut mempromosikan keadilan kepada semua tanpa mengira bangsa, agama, jantina atau status sosial, ekonomi serta politk. Undang-undang tersebut hendaklah juga memberi manfaat kepada manusia sejagat dan bukan sahaja kepada kaum Muslimin. Akhirnya, undang-undang tersebut harus memenuhi keperluan Maqasid al-Syariah. Sekiranya dilihat secara amnya, kebanyakkan undang-undang di Malaysia boleh dianggap Islamik pada dasarnya. Malangnya, aspek ini kurang diberi perhatian oleh para cerdik pandai. Ini menyebabkan banyak pendapat yang mengatakan bahawa kesemua undang-undang di Malaysia adalah tidak Islamik. Perkara ini menunjukkan keperluan untuk terus mengkaji isu ini bagi mencadangkan garis panduan bagi menetukan keIslaman sesuatu undang-undang itu, dan inilah yang cuba dilakukan dalam makalah ini.
\end{abstract}

Kata kunci: undang-undang Islam, Maqāṣid al-Sharī'ah, ta’zīr, hak asasi manusia 


\section{INTRODUCTION}

Islam is not simply a religion but a complete, comprehensive civilisation. ${ }^{1}$ Islam comes with principles governing mankind not just in their daily rituals but also by introducing laws that promote and protect human rights and, prior to it, establishes responsibilities. It is not concerned simply with the relationship between the Creator and the created but also between people when interacting with each other as well as with the universe. Allah S.W.T says:

"Today I have perfected your religion for you and completed my grace upon you and have chosen for you Islam as your religion". ${ }^{2}$

Islam is meant to be practiced by every Muslim, hence the messengers of Allah came with revelations specifying rules to settle disputes and safeguard the community from crisis. Allah S.W.T further says:

"We have already sent Our messengers with clear evidences and sent down with them the Scripture and the balance that the people may maintain [their affairs] in justice. And We sent down iron, wherein is great military might and benefits for the people, and so that Allah may make evident those who support Him and His messengers unseen. Indeed, Allah is Powerful and Exalted in Might."3

Being complete and comprehensive, Islam covers, among other things, three essential areas of human life: physical, intellectual and spiritual. These three pillars of the faith are known individually as $R u k n$ Islam (pillars that relate to Divine law), Rukn Imān (pillars of belief), and I $\bar{s} \bar{a} n$ (ethics and moral character). Islam, deals primarily with the physical aspects of the faith, such as its obligations, prohibitions and recommended actions. This part of the faith is governed by the Shari'ah, or the Islamic law. Under ideal circumstances, the Shari'ah should be implemented and must be complemented by the other two. The Prophet (s.a.w.) taught all these three pillars at once, through a natural and holistic approach.

${ }^{1}$ Yusuf al-Qardhawi, General Characteristics of Islam (Cairo: Islamic Publishing \& Distribution, 1985), 9, 15.

${ }^{2}$ Al Quran, Surah al-Maidah, 4: 13.

${ }^{3} \mathrm{Al}$ Quran, Surah al-Hadid, 57: 25. 
However, the Shari'ah is not meant to dictate human actions but allows room for the use of reason. Islam sanctions the use of reason to conduct people's affairs. The ability to use one's reasoning is a blessing, whereby every human being is granted the power to distinguish between good and evil so that they can live their life as ordained by Allah S.W.T. ${ }^{4}$ Those who fail to appreciate and properly utilize their reason are like those, in the words of the Qur'an, who :

“... have hearts with which they do not understand, they have eyes with which they do not see, and they have ears with which they do not hear. Those are like livestock; rather, they are more astray. It is they who are the heedless."

Similarly, the Shari'ah does not dictate to people the type of legal system they must follow in a strict sense. The manner of leadership and methods of government are largely left to the people to decide and opportunity is given to those who are awarded power or chosen by the people to use their wisdom in deciding what is best for the society at large. This includes the use of reasoning to carefully choose the system and procedure that will assist them in delivering justice and to settle disputes amongst themselves. The Shari'ah sets the general rules and guidelines that must be followed. These include the rights that must be granted, for example, to the accused person, the responsibility to judge fairly between the disputing parties, and also the responsibility to uphold justice regardless of the people's faiths and races. Allah S.W.T says in the Holy Quran:

"O you who have believed, be persistently standing firm in justice, witnesses for Allah, even if it be against yourselves or parents and relatives. Whether one is rich or poor, Allah is more worthy of both. So follow not [personal] inclination, lest you not be just. And if you distort [your testimony] or refuse [to give it], then indeed Allah is ever, with what you do, acquainted."

This flexibility can be seen in the distinction between the law relating to the implementation of hadd and ta'zir punishments The major difference between hadd and ta'zir is that the former is fixed and not

${ }^{4}$ Anwarullah. The Criminal Law of Islam. (New Delhi: Adam Publishers \& Distributors, 2010), 10.

${ }_{5}^{5}$ Al Quran, Surah al-A'raf, 179.
${ }^{6}$ Al Quran, Surah an-Nisa, 135. 
open to variation while the latter is flexible enough to accommodate the ever-changing circumstances in the society. This distinction has, however, not been properly understood in countries where Sharī'ah is said to be applied. For instance, the 1983 Penal Code of Sudan, contains $h u d \bar{u} d$ provisions but it gives extensive powers to courts to punish people at their discretion based apparently on the Islamic penal law principle of $t a$ 'zir (discretionary punishment intended to deter), even if a given act was not identified as a crime in the Penal Code. In some countries like Pakistan, $t a ' z \bar{i} r$ is commonly used instead of implementing corporal punishment $(h u d \bar{u} d)$ except in the case of crimes that necessitate execution. This has led to a myriad of confusion and misunderstanding.

There are other examples. Islamic law in Malaysia is under the jurisdiction of the states (Article 74(2)) and also the Federal government. The States are only allowed to enact laws pertaining to Muslims personal laws and its related personal conducts. This include criminalization of acts like close proximity (khalwat) with a non-mahram, ${ }^{7}$ drinking liquor ${ }^{8}$ and also sexual intercourse outside of wedlock. ${ }^{9}$ For some, the legal system being implemented in Malaysia is still far from being acceptable as truly an "Islamic" system.

Furthermore, there exists a parallel legal system of Shari'ah court and the Civil court system under the Federal Constitution. Articles 121 and 121(1A), has led to a dichotomy between Islamic and Civil law. Under this unique system, both the Syariah and Civil courts operate side by side with their own exclusive jurisdiction with no room for interference by either one. And as decided by previous court cases, both courts guard their respective jurisdictions independently against the interference of the other. It is easy to find writings that erroneously confine Islamic law to just the personal law of the Muslims whereas all other laws are considered as Civil law. ${ }^{10}$ The consequence of this dichotomy is that it

${ }^{7}$ Section 27 of the Syariah Criminal Offences (Federal Territories) Act 1997 ${ }^{8}$ Ibid, Section 19

${ }^{9}$ Ibid, Section 23

${ }^{10}$ See Abdullah Saad Alarefi, “An overview of Islamic Law," Internatioanal Criminal Law Review, 9:4 (2009), 707-731; Michael G. Peletz, "Malaysia's Syariah Judiciary as Global Assemblage: Islamization, Corporatization and Other Transformations on Context," Comparative Studies in History and Society Vol. 55: 3 (2013), 603-633; Kevin Reinhart (1983) "Islamic law as Islamic Ethics", Journal of Religious Ethics 11:2 (1983), 186-203; Luke 
separates Islamic and Civil laws into two distinctive spheres with no intersection except for highly contentious matter such as conversion to Islam and annulment of marriages between converted spouses. This consequently leads to a tension between the Muslims and non-Muslims in Malaysia. $^{11}$

Therefore, the appropriate way to analyse the Islamic value of a law is by analysing the law itself to determine whether it contains anything that is against the teaching of Islam. If it does not, then the law could be considered as being "Islamic".

Other than that the segregation of laws between Muslims and nonMuslims in Shari'ah courts and in several statutes also defeats the purpose of achieving justice for all, which is clearly against the teaching of Islam. The Shari'ah is meant to cater to all, not only Muslims. Hence, the laws, especially those deemed to be "Islamic" should not ignore the rights of the non-Muslim parties especially in family law matters, which are dealt at only in the civil courts and cases like this should be dealt with hikmah i.e., wisdom by putting things in their proper places and assigning them to their proper status. However, in order to ensure that laws enacted by the people are just, Islam provides a number of general rules that must be observed by the people especially those with the authority to enact laws.

The objective of this article is to highlight the requirements for a law to be considered Islamic. A law enacted by quoting countless Islamic sources may not be necessarily considered Islamic if it fails to adhere to the principles of:

1. Equality before the law;

2. Justice;

3. The protection against persecution;

4. Maqāṣid al-sharī'ah;

5. Morality, hikmah, and rahmah.

Kreider, "Moral Development and the Islamic Ethics of Pluralism," Jefferson Journal of Science and Culture, 1:4 (2016), 52-61.

${ }^{11}$ Indira Ghandi a/p Mutho v Ketua Polis Negara [2016] 3 MLJ 141. 
These requirements will be discussed in the sections that follow. The discussion is inevitably based on the Qur'an and the Sunnah of the Prophet Muhammad (s.a.w.). The views of the majority of Muslim jurists are adduced, wherever applicable. The constitutional documents and court cases have also been examined.

\section{EQUALITY BEFORE THE LAW}

It is inadequate to discuss the Islamic value of a law without mentioning the concept of equality before the law. Equality before the law is one of the basic principles of the Islamic justice system. This principle suggests dealing with every member of the society equally without any favour towards specific classes or races. Everyone should receive the same treatment and be guaranteed the same right according to the law. The Qur'an is emphatic about equality. It reads:

"O humankind, indeed We have created you from male and female and made you peoples and tribes that you may come to know one another. Indeed, the most noble of you in the sight of Allah are those of you with taqwā. Indeed, Allah is Knowing and Acquainted." 12

Equality in Islam is an article of faith to which Muslims must sincerely adhere to. The foundations of this Islamic value of equality are deeply rooted in the structure of Islam. It stems from basic principles such as the following:

(1) All men are created by One and the Only God, the Lord of the universe.

(2) All mankind belong to the human race and share equally in the common parentage of Adam and Hawwa.

(3) Allah is Just and Kind to all His creatures. He is not partial to any race, age or religion.

(4) All people are born equal, in the sense that no one brings any possession with him; and they die equal in the sense that they take back nothing of their worldly belongings.

(5) Allah judges every person on the basis of his own merits and according to his own deeds.

\footnotetext{
${ }^{12}$ Al Qur'an, al-Hujarat, 49:13.
} 
These are some of the principles behind the value of equality in Islam. This concept, when well understood and fully implemented, leaves no room for prejudice or persecutions.

The Qur'an rejects the principle of inequality and recognises $t a q w \bar{a}$ as the criterion for distinction. The best of us and most honoured of us therefore, according to the Quran, are those who have taqwa which is that form of higher consciousness of Allah that enables believers to become both "personifications" of the highest values enunciated by the Qur'an and representatives of the most endearing qualities of Prophethood. The Prophet Muhammad s.a.w reminded the Muslims, on the occasion of the conquest of Mecca in 630, saying that:

"O people! Your Creator is one, and you are all descendants of the same ancestor. There is no superiority of an Arab over a non-Arab, nor of the black over the red, except on the basis of righteous conduct $(\operatorname{taq} w \bar{a})$." 13

At that moment of triumph, the Prophet s.a.w affirmed human equality beyond colour and race, which are to be seen as basis only of identity and recognition. Taqwa $\bar{a}$ alone set the evaluative standards of human conduct. He warned people about the danger of failing to uphold this right. He warned:

"The people before you were destroyed because they used to inflict the legal punishments on the poor and forgive the rich. By Him in Whose Hand my soul is! If Fatimah (the daughter of the Prophet) indeed does that (i.e. stealing), I would cut off her hand." 14

According to yet another hadith, the Prophet said: "There is no superiority of an Arab over a non-Arab, or of the black over the red, except on the basis of righteous conduct." ${ }^{\prime 5}$ The Islamic outlook on equality thus marked a departure from the Hellenistic thought and Judaism and the like which considered some as inherently superior to others. Ancient India regarded all other races and nations as unclean. It

${ }^{13}$ See Aḥmad Ibn Ḥanbal, Musnad al-Imām Aḥmad Ibn Hanbal (Beirut: Dār alFikr, n.d.), 6: 570.

${ }^{14}$ Sahih Muslim (tr. Abdul Hamid Siddiqui), Vol. 3, Hadith No.4187 (Delhi: Kitb Bhavan, 2000), 1096-1097.

${ }^{15}$ Extract from the Prophet's sermon on the occasion of the Farewell pilgrimage. Ahmad Ibn Rabbih, al- 'Iqd al-Farid li'l-Malik al-Said (Cairo: Matba'ah Lajnat al-Ta'lif, 1384/1965), II, 357. 
had even divided its own people into four classes, allowed all the rights and privileges to the top three and condemned the fourth, the Sudras, to the level of sub-human species and even denied the right to worship God like others. The Romans arrogated themselves as the masters of all other nations while the Jews claimed to be the children of God thereby justifying them to look down upon others as gentiles. Europe in contemporary times considers the white races to be superior to the coloured ones. ${ }^{16}$ However, the message brought by the Prophet Muhammad s.a.w abolished every distinction and prejudice of colour and race fourteen centuries ago. On the day Mecca was conquered, he declared:

"O Quraish, God has taken from you the haughtiness of paganism and its veneration of ancestors. Man springs from Adam, and Adam sprang from dust." 17

Thus for a law to be considered as Islamic, it must first provide for equal treatment to all members of the society. Laws that segregate the members of the society such as the Apartheid laws in South Africa apparently cannot be considered Islamic, no matter how beneficial it is to the white people as it discriminates human beings and promotes unfairness, in fact, injustice. ${ }^{18}$ Good and benefit must be seen in the context of the whole society and not just in the light of a part or group of the society. A law that is biased towards the higher ranking members would only sow seeds of discontent among those of the lower ranks which will lead to chaos and social anarchy. Islam introduced equality that benefits all the people.

In Malaysia, the principle of equality is enshrined under Article 8 of the Federal Constitution as one of the fundamentals of human rights. Article 8(1) prescribes that:

"All persons are equal before the law and entitled to the equal protection of the law."

Article $8(2)$ reads:

\footnotetext{
${ }^{16}$ MacDougall, Hugh A. Racial Myth in English History: Trojans, Tentons, and Anglo-Saxons (Montreal: Harvest House, 1982), 91-92.

${ }^{17}$ Ibn Ishaq, The Life of Muhammad (tr. Alfred Gillaume) (Oxford: Oxford University Press, 2002), 53.

${ }^{18}$ Tiryakian, Edward A. "Apartheid and Politics in South Africa." The Journal of Politics, Vol. 22, no. 4 (1960): 682-97.
} 
"Except as expressly authorized by this Constitution, there shall be no discrimination against citizens on the ground only of religion, race, descent, place of birth or gender in any law or in the appointment to any office or employment under a public authority or in the administration of any law relating to the acquisition, holding or disposition of property or the establishing or carrying on of any trade, business, profession, vocation or employment."

Article 8 contains two additional sub-clauses worth noting which are as follows:

(3) there shall be no discrimination in favour of any person on the ground that he is a subject of the Ruler of any State.

(4) no public authority shall discriminate against any person on the ground that he is resident or carrying on business in any part of the Federation outside the jurisdiction of the authority.

Thus, Article 8 guarantees that everyone will be given fair treatment and no one can be discriminated against their religion, race and gender. This right is very important especially in settling disputes among different classes of the society. It is important that during the court adjudication both parties, regardless of their class or status, be treated equally and the judge should never treat any party differently than the other. Islam recognises and upholds this right as it is very crucial towards the delivery of justice in society. Allowing favouritism among the different classes of people will lead to the collapse of the society as animosity among them will grow and the judicial system will be seen as unable to provide justice and fairness to the lower echelon of the society. Under the Islamic code of ethics for judges, a judge is ordained to provide equal treatment to the disputing parties whether internally or externally. Even the gestures of the judge against the disputing parties must be made similar without showing any sign of favouritism to either party. ${ }^{20}$ And the judge must also give equal treatment even in disputes between a father and a son, the

${ }^{19}$ Federal Constitution (As at 1 November 2010)(Kuala Lumpur: Percetakan Nasional Malaysia Berhad, 2010).

${ }^{20}$ Ahmad Ibrahim \& Mahmud Saedon Awang Othman, "Judges and Lawyers under the Shari'ah", in Islam \& Justice, Aidit Ghazali, ed. ( Kuala Lumpur: IKIM 1993) 134-136. 
aristocrats and the commoners, and between Muslims and non-Muslims. ${ }^{21}$ Even though there might be different procedures in certain areas such as consideration of oath during trials, 22 there should never be any major differences between the right of a Muslim and the right of a non-Muslim before the law.23 As the one who adjudicates between the disputing parties, it is very important that a judge is to be seen as being fair to both parties, as per the maxim that justice must be seen to be done. Any judge who is unable to provide equal treatment to both parties must recuse himself from hearing the case.

\section{JUSTICE}

A discussion on equality necessitates a discussion justice. For justice, the Qur'an uses the word 'Adl, Qist and sometimes Taswiyah. The Qur'an states: "And do not let ill-will toward any folk incite you so that you swerve from dealing justly. Be just, that is nearest to heedfulness" 24 The Qur'an is very emphatic:

"O ye who believe, stand out firmly for justice, As witnesses to Allah, Even As against yourselves, or your parents, or your kin, and whether it be (against) rich or poor: for Allah can best protect both. Follow not the lusts (of your hearts), lest ye swerve, and if ye distort (justice) or decline to do justice, Verily Allah is well-acquainted with all that ye do." 25

The Universal Islamic Declaration of Human Rights, based on the Qur'an and the Sunnah of Prophet Muhammad PBUH, provides that every person has the right "to obtain fair adjudication before an independent judicial tribunal in any dispute with public authorities or any

${ }^{21}$ Niz̄ām, and Hasan Bin Mansūr. Awzjandī. Al-Fatāwā Al-Hindiyyah: Almusammā Bi Al-Fatāwā Al- 'Ālāmkīriyyah. Bayrūt: Dār Ihyā Al Turāth Al'Arabī, 1310, Vol. 3, 324.

${ }^{22}$ Bassiouni, M. Cherif. The Islamic Criminal Justice System. (London: Oceana Publications, 1982). p. 23.

${ }^{23}$ Malekian, Farhad. Principles of Islamic International Criminal Law: A Comparative Search. (Leiden: Martinus Nijhoff, 2011) 375-384

${ }^{24} \mathrm{Al}$ Qur'an, Surah al Maidah, 5: 8.

${ }^{25}$ Al Qur'an, Surah al Nisa, 4: 135 
other person." ${ }^{26}$ The Qur'an enjoins both the leaders and judges to ensure justice. Allah S.W.T states: "Whenever you judge between people, you should judge with (a sense of) justice." ${ }^{27}$ Evidently, rendering justice to all is an obligation for every Muslim. This is rooted in the fair hearing and due process of law in both civil and criminal proceedings. ${ }^{28}$

Justice entails the following criterion:

(1) Equality (Musāwah);

(2) Moderation (Tawassut or I'tidāl);

(3) Trust (Amānah); and

(4) Solidarity (Ta'āwun).

It follows, firstly that to preserve justice in society, there should not be any type of superiority, privilege and priority on the basis of language, colour and class. All human beings should be treated as equals without any distinction. Secondly, moderation is essential for the prevalence of justice in society. The Qur'an declares Muslims to be a community whose members are moderate in all spheres of life. Thirdly, man is declared to be the vicegerent of Allah on this earth and is held accountable for what is given in his control, Finally, solidarity and co-operation plays a very important part in implementing justice and establishing a stable society. Thus, the Qur'an declares, "And help one another in righteousness and piety and help not one another in sin and aggression, and keep your duty to Allah." 29

In Malaysia, access to justice forms an integral part of art. 8(1) of the Federal Constitution. This is stated by the Court of Appeal in Kekatong Sdn Bhd v Danaharta Urus Sdn Bhd. ${ }^{30}$ The Court declared that fundamental liberties guaranteed by Part 11 of the Constitution, including article $8(1)$, should receive a broad, liberal and purposive construction.

${ }^{26}$ C.G. Weeramantry, Islamic Jurisprudence (Kuala Lumpur: The Other Press, 2002).

${ }^{27}$ Al Qur'an. Surah al- Nisa, 4: 58.

${ }^{28}$ See Awad, A. M., "The Rights of the Accused under Islamic Criminal Procedure" in The Islamic Criminal Justice, Bassiomi, M. C. (ed.) (New York: Oceana Publications, 1982).

${ }^{29}$ Al Qur'an, Surah al Maidah, $5: 2$.

${ }^{30}$ [2003] 3 CLJ 378. 
The court was to decide whether section 72 of the Pengurusan Danaharta National Berhad Act 1998, which prohibited the court from granting injunctive relief against Danaharta Nasional Sdn Bhd and its subsidiaries, was ultra vires the Constitution. The court held that section 72 was contrary to the rule of law housed within article 8(1) of the Constitution, because it failed to meet the minimum standards of substantive and procedural fairness by denying an adversely affected litigant the right to obtain injunctive relief against the respondent in any circumstances. ${ }^{31}$ During the proclamation of independence, Tunku Abdul Rahman Putra declared that, ".... as from the thirty first day of August nineteen hundred and fifty seven, the Persekutuan Tanah Melayu ... shall be forever a sovereign democratic and independent state founded upon the principle of liberty and justice and ever seeking the welfare and happiness of its people and the maintenance of a just peace among all nations." 32

\section{PROTECTION AGAINST PERSECUTION}

Islam guarantees to the people the protection against persecution. No one is allowed to persecute anyone without undergoing due process. Islamic criminal law also includes the procedural aspects of the law, which includes certain rights given to the accused person in order to safeguard his interest. No one can be sentenced for a crime that has not been proven against them. The state can prosecute only by adhering to its due process obligation. One of the safeguards against persecution is the presumption of innocence against an accused person. Islam celebrates this right where the Prophet mentioned that in case of doubt, no punishment should be inflicted against the accused person. This presumption of innocence brings with it the requirement that the accuser must establish his case against the accused person and no the other way around. The burden of proof will always lie upon the accuser and he must satisfy a certain degree of certainty before the accused person is to defend himself.

In Malaysia, an accused person enjoys this right whereby he/she does not have to raise any defence unless the prosecutor manages to prove beyond reasonable doubt that all the elements of the crime have been fulfilled. To proceed with the prosecution, the prosecutor must prove

\footnotetext{
${ }^{31}$ Ibid., 379.

${ }^{32}$ Tunku Abdul Rahman, 'Proclamation of Independence', Merdeka Statdium, Kuala Lumpur, 31 August 1957.
} 
prima facie up to the extent that if the accused person chooses to remain silent then the evidence adduced by the prosecutor is enough to prove the ingredients of the crime that the accused person is accused of. ${ }^{33}$ It is only after this prima facie stage has been established that the accused person is required to enter his defence. And regardless of the fulfilment of the requirements, if the accused person manages to cast a reasonable doubt upon the prosecutor's case, the court will have to set him free. This is of course in line with the principle under Islamic law. In one hadith the Prophet mentioned that:

Had men been believed only according to their allegations, some persons would have claimed the blood and properties belonging to others, but the accuser is bound to present positive proof. ${ }^{34}$

And according to a maxim under Islamic law:

"Al-bayyinah ala al-mudda ' $i$ wa al-yamin ala man ankara. ",35

[The burden to prove is upon the accuser and the oath is upon the accused]

Under the Islamic law, accusation must be based on sound evidence that negates any doubt. If the accuser fails to produce enough evidence to establish his case, then the court may throw his case out and decides in favour of the other party as in Islam, a case cannot be built upon mere probability, ${ }^{36}$ be it under the criminal or even under the civil cases. The only difference would be the degree of certainty required for each case. Islam does not allow people to be persecuted, without trial, even though it was allegedly done in the name of common good. An accused person deserves the right to presumption of innocence and the protection against torture. There are many instances in history where the accused was set free for the inability of the accuser to prove the case. One of the famous companion of the Prophet, Ali ibn Abi Talib accused a Jew for stealing his armour. Ali could not provide enough evidence to support his claim and the case was subsequently decided in favour of the Jew. This is one of many cases in the history of Islam, which shows the court strictly

\footnotetext{
${ }^{33}$ Balachandran v Public Prosecutor [2005] 2 MLJ 301.

${ }^{34}$ Al Baihaqi, The Forty Hadith of Imam al-Nawawi, No. 33.

${ }^{35}$ Maj. 'Adliyyah, art. 76.

${ }^{36}$ Ibid. at no. 21 p. 67
} 
upholding the presumption of innocence against an accused person in order to avoid unjust persecution. A person, regardless of his/her social status, will be deemed equal before the law and no one can make a claim without backing it up with proper evidence.

\section{MAQĀSTID AL-SHARI'AH}

Maqāsid al-sharì'ah refers to a purpose, objective, principle, intent, and goal behind the Islamic rulings. To many legal theorists, it is an alternative expression to people's interests. Some jurists used the terms maqūsid and public interests interchangeably. It is generally agreed by scholars that a maqāssid, purpose, objective, principle, intent, goal, end, or principle in the Islamic law is meant for the "interest of humanity." According to al-Shatibi, maqāsid is the fundamentals of religion, basic rules of the law, and universals of belief. ${ }^{37}$ Traditionally, maquasid has been divided into three "levels of necessity," which are necessities (darūrāt), needs (hājīyāt), and luxuries (tahsīnīya $\bar{t}$ ). Necessities are further classified into five as follows:

1. Preservation of religion.

2. Preservation of life.

3. Preservation of lineage.

4. Preservation of wealth.

5. Preservation of intellect. ${ }^{38}$

Some jurists added "the preservation of honour" to the above five widely popular necessities. ${ }^{39}$ These necessities were considered essential matters for human life itself. There is also a general agreement that the preservation of these necessities is the objective behind the Islamic law.

These objectives of the Shari'ah play a big role in determining whether a law is "Islamic" or not. As alluded earlier, a law need not be derived directly from the Quran or Hadith. As long as the law complies with the general spirit of Islam, it may be deemed as Islamic. The objectives of the Shariah can be used as a yardstick in determining the

\footnotetext{
${ }^{37}$ Al-Shatibi, Al-Muwafaqat fi usl al-Ahkam (Concordances in the Priniciples of Jurisprudence), ed., M. Munir (Cairo: np. 1922/1341), vol. 2, p. 7.

${ }^{38}$ Abu Hamid Muhammad ibn Muhammad Ghazali, Al Mustafa min 'Ilm alUsul (Cairo: Al-Maktabah al-Tijaniyyah, 1356/1937), vol. 1, p.42.

${ }^{39}$ Al-Shatibi, Al-Muwafaqat fi usl al-Ahkam, vol. 3, p. 17.
} 
Islamicity of the law. For example, the second caliph, Saidina Omar, for example, imposed a moratorium on the punishment for theft during the famine of Madinah. He thought that applying the punishment prescribed in the Qur'an and the Sunnah in a literal way, while people are in need of basic supplies for their survival, goes against the general principle of justice, which he considered more fundamental. This was an interpretation of the Quran in light of maq $\overline{a s i d} .{ }^{40}$ Likewise, a law that seeks to prevent harm against the healthy mind of a person such as the Dangerous Drugs Act, then the law can be considered Islamic as it promotes one of the objectives of shari 'ah, i.e. the protection of reason.

It has been observed by many scholars that the regimes in the Middle East controlled by the army, in alliance with business and religious elites, or tribal elites have consistently resorted to any method of interpretation that serves their material and political interests. They quite conveniently put on "Islamic" masks to usurp power to support their political ends. Some authoritarian regimes put on an "Islamic" mask at times of oppression of Islamic parties and groups, in order to ward off accusations that they are against Islam. Their objective in these instances is to appeal to the masses at a time of an election or public protests. At other times, the same authoritarian regimes resort to un-Islamic practices to appeal to secular/western powers as their allies and ideological extensions. ${ }^{41}$

In contrast, the Federal Constitution of Malaysia contains certain rights under the chapter on Fundamental Liberties that reflect the objectives of the Shari'ah. Article 5 (1) of the Constitution provides that:

"No person shall be deprived of his life or personal liberty save in accordance with law."

This provision guarantees protection to people from unjustified killing and other acts that threaten their life. This means murder but also include any other actions that can deprive a person of his/her livelihood.

\footnotetext{
${ }^{40}$ Mohammad Biltaji, Manhaj Omar Ibn Al-Khatab Fil Tashree' (Cairo: Dar alSalam, 2002), 190.

41 Jasser Auda, Al-Dawlah al-madaniyyah: Nahwa tajawuz al-istibdad wa tahqeq maqā̂Iid al-shar $\hat{E}$ 'ah (Civil State: Toward Overcoming Authoritarianism and Realizing the Objectives of the Shariah) (Beirut: Arab Network for Research, 2015), pp. 7-11.
} 
The guarantee that is provided under this provision has been interpreted by the Court to also include protection of livelihood. ${ }^{42}$

Similarly, article 12 (1) of the Constitution provides that:

"Without prejudice to the generality of Article 8, there shall be no discrimination against any citizen on the grounds only of religion, race, descent or place of birth-

(a) in the administration of any educational institution maintained by a public authority, and, in particular, the admission of pupils or students or the payment of fees; or

(b) in providing out of the funds of a public authority financial aid for the maintenance or education of pupils or students in any educational institution (whether or not maintained by a public authority and whether within or outside the Federation)."

This provision provides for the right of the people towards education. As stated in the Article, no one can be deprived from having access towards education on the ground of religion, race and descent. This is in line with the preservation of intellect, one of the objectives of the Shari'ah.

Likewise, Article 13 of the Constitution provides for the right to property:

(1) No person shall be deprived of property save in accordance with law.

(2) No law shall provide for the compulsory acquisition or use of property without adequate compensation.

This provision provides for the right of a person to accumulate wealth and to protect him from any deprivation of his wealth through unlawful means. Even in the event of compulsory acquisition of property as provided for under the Compulsory Acquisition of Land Act, the government is compelled to make good of the acquisition with adequate compensation to the deprived person. And surely this is in line with one of the objectives of Syariah which is preservation of wealth. Islam guarantees the right of the people to own property and to accumulate wealth. Islam never allows its followers to live in destitute. There are many instances of wealthy saha a bah during the time of the Prophet who

${ }^{42}$ Adong bin Kuwau [1998] 2 MLJ 158 at p 164 
were allowed to accumulate wealth as long as it is done through lawful means.

There are many other examples of laws in Malaysia that are in line with the objectives of the Shari'ah. And while some of these laws do not mention or quote any religious texts as a basis, their purpose is still in tandem with the objectives of the Shariah. Some of these laws are discussed as in the following paragraph.

Article 11(4) of the Constitution accords power to the State governments to enact laws against the propagation of any religious beliefs among the Muslim. This law fulfils the objective of preserving the religion or faith of the Muslim by forbidding non-Muslim from propagating their religion to the Muslims. Pursuant to this Article, State governments had enacted laws such as the Enakmen Kawalan Dan Sekatan Pengembangan Agama Bukan Islam 1988 of Kedah and also Enakmen Kawalan Dan Sekatan Pengembangan Agama-Agama Bukan Islam 1989 of Pahang. It is highly possible that this law is enacted to be in line with the spirit of a reminder from Allah as in the Qur'an:

"And whoever desires other than Islam as religion - never will it be accepted from him, and he, in the Hereafter, will be among the losers." $" 43$

Under the Malaysian Penal Code, there are many crimes that are being incorporated with capital punishments with the objective of protecting the life of the public. These include the crime of murder ${ }^{44}$ and culpable homicide. ${ }^{45}$ It is also important to note that we also have laws that protect the livelihood of the people such as the law against the destruction of nature, for example, the Environmental Quality Act 1974. Under this law, express provisions are provided to restrict many types of pollution including atmospheric pollution, ${ }^{46}$ noise pollution, ${ }^{47}$ soil pollution ${ }^{48}$ and also inland waters pollution. ${ }^{49}$ Indeed Allah says that:

\footnotetext{
${ }^{43}$ Al Quran, Ali-'Imran, 85

${ }^{44}$ Section 300 \& 302, Penal Code

${ }^{45}$ Section 299, Penal Code

${ }^{46}$ Section 22, Environmental Quality Act 1974

${ }^{47}$ Section 23, Environmental Quality Act 1974

${ }^{48}$ Section 24, Environmental Quality Act 1974

${ }^{49}$ Section 25, Environmental Quality Act 1974
} 
“... We decreed upon the Children of Israel that whoever kills a soul unless for a soul or for corruption [done] in the land - it is as if he had slain mankind entirely. And whoever saves one - it is as if he had saved mankind entirely. And our messengers had certainly come to them with clear proofs. Then indeed many of them, [even] after that, throughout the land, were transgressors." 50

The Birth and Death Registration Act 1957 makes it mandatory for the registration of birth. Under this law, failure to register the birth of a child is considered an offence with monetary punishment of up to RM250. ${ }^{51}$ The importance of this law is to enable the government to ensure that, children born will be legally recognised and the lineage can be properly traced to the legitimate parents. ${ }^{52}$ If the question of lineage is not properly established, there will be problems such as inheritance resulting from the inability to properly prove the rightful lineage. With this law, the question of lineage can be properly addressed with a proper record and register to help identify the lineage of a child to his father. This again is in line with the Hadith of the Prophet which reads: "The child (born as a result of lawful marriage) belongs to the (bed of) his father." 53

Under the Malaysian Penal Code, criminal offences against property are provided under many sections to include theft, ${ }^{54}$ robbery, ${ }^{55}$ gangbangrobbery, ${ }^{56}$ criminal breach of trust, ${ }^{57}$ and also dishonestly receiving stolen property. ${ }^{58}$ They carry harsh penalties to deter the commission of the crimes. This is important in order to ensure that the wealth and the property of the people are well protected and no one can arbitrarily take someone's property against his/her will.

At the same time there are also laws that deal directly with the administration of property. The National Land Code 1965, for instance, provides for the rules relating to ownership of land in Malaysia. And in

\footnotetext{
${ }^{50}$ Al Quran, Al-Maidah, 32

${ }^{51}$ Section 35, Birth and Death Registration Act 1957

${ }^{52}$ Section 7(2), Birth and Death Registration Act 1957.

${ }^{53}$ Reported by Bukhari no.2105 and Muslim no.1457.

${ }^{54}$ Section 378, Penal Code.

${ }^{55}$ Section 390, Penal Code.

${ }^{56}$ Section 391, Penal Code.

${ }^{57}$ Section 405, Penal Code.

${ }^{58}$ Section 411, Penal Code.
} 
Malaysia, the principles of fixture and chattel are applied where the house is considered to be part of the land. As such when we talk about property in Malaysia, the ownership of a house will include the ownership of the land as well (except for cases of strata titles). Therefore, the National Land Code protects the registered owner's rights to his own property (in terms of land ownership). In addition, we also have the Land Acquisition Act 1960 which lays out the procedures for government acquisition of private land where the government is required to pay compensation to the landowners. ${ }^{59}$

This protection guarantees the right to accumulate wealth and property which is in line with what is mentioned by Allah:

"And do not consume one another's wealth unjustly or send it [in bribery] to the rulers in order that [they might aid] you [to] consume a portion of the wealth of the people in sin, while you know [it is unlawful]."

Dangerous Drugs Act 1952 is the main Act that deals with the prohibition of dangerous drugs in Malaysia. This law encompasses a wide array of drugs such as cannabis, ${ }^{61}$ opium, ${ }^{62}$ and amphetamine. ${ }^{63}$ The Act also provides the mandatory death penalty for drug traffickers if they satisfy the minimum amount of drugs stipulated in the Act. ${ }^{64}$ This shows that the government is serious in tackling the threat of drugs and related issues. It is commonly known that arbitrary consumption of drugs can cause adverse impacts on a person's intellectual capacity and thus it cannot be allowed in order to protect the society at large. The effect of such illicit consumption of drugs into the body will lead to other harms such as crimes and health problems not only among the drug addicts but the people around them as well.

This is analogically in line with the prohibition of intoxicants where Allah says:

"O you who have believed, indeed, intoxicants, gambling, [sacrificing on] stone alters [to other than Allah], and divining arrows are but

\footnotetext{
${ }^{59}$ Section 12(1), Land Acquisition Act 1960.

${ }^{60}$ Al Quran, Al-Baqarah: 188.

${ }^{61}$ Part I, First Schedule Dangerous Drugs Act 1952.

${ }^{62}$ Part II, First Schedule Dangerous Drugs Act 1952.

${ }^{63}$ Part III, First Schedule Dangerous Drugs Act 1952.

${ }^{64}$ Section 39B, Dangerous Drugs Act 1952.
} 
defilement from the work of Satan, so avoid it that you may be successful." 65

The above examples highlight how the objectives of the law in Malaysia are in tandem with the objectives of the Shari'ah. The laws may not be derived directly from the Quran and Sunnah but still they provide for the accomplishment of the objectives of Shari'ah.

As for the preservation of honour, the Penal Code deals with harsh punishment for crimes committed against the honour of a person. Such crimes include rape, ${ }^{66}$ gang rape ${ }^{67}$ and also carnal intercourse against the order of nature without consent. ${ }^{68}$ What is carnal intercourse against the order of nature? section 377A defines it as, "Any person who has sexual connection with another person by the introduction of the penis into the anus or mouth of the other person is said to commit carnal intercourse against the order of nature." ${ }^{19}$ Further, section $77 \mathrm{~B}$ provides that it is an offence even if it was done with consent of the parties and the punishment for such a crime is imprisonment for a term which may extend to twenty years, and shall also be liable to whipping. As for those committing carnal intercourse without the consent, or against the will, of the other person, the punishment shall be, "....imprisonment for a term of not less than five years and not more than twenty years, and shall also be liable for whipping."70

It can be observed that there are many laws enacted by the government that aims at protecting the necessities of life. These laws may not have referred to the Shari'ah but the implication is the same. Some countries have made maqāsid al-shari' 'ah a national agenda. In Malaysia, maqāsid al-shari' 'ah has become a national agenda with the launch of the Shari'ah Index, a governance metric that uses maqāsid principles to gauge the country's performance from the Islamic outlook.

\footnotetext{
${ }^{65}$ Al Quran, Al-Maidah, 90.

${ }^{66}$ Section 375, Penal Code.

${ }^{67}$ Section 375B, Penal Code.

${ }^{68}$ Section 377C, Penal Code. It is to be noted that in Malaysia carnal intercourse against the order of nature is an offence whether consented or not. This include blowjob and anal sex done between consenting adult.

${ }^{69}$ Subs. by Act A727 w.e.f. 5 May 1989.

${ }^{70}$ Ins. by Act A727 w.e.f. 5 May 1989.
} 


\section{MORALITY, HIKMAH AND RAHMAH}

In Islam, the creation of law must necessarily affect the morality aspect too. In other words, law and morality cannot be separated. Morality can be defined as virtue, akhlāq or behaviour and includes the concept of righteousness, good character and the body of moral qualities and virtues enshrined in the Qur'an and the Sunnah of the Prophet (s.a.w.). Islam requires mankind to behave morally and treat each other in the best possible manner to please Allah. It emphasizes maintaining justice, being honest, fulfilling promises and being kind to parents. Morality is also associated with the inner part of one's $\bar{i} m \bar{a} n$. It is widely regarded that the morality of a Muslim reflects the quality of $\bar{i} \bar{a} n$. The morality aspect that exists in a law is an index of the morality in a community. To claim that a law is Islamic, one must also look at the practicality of the law. This aspect is important because the Creator of the law knows what the needs of His creations are and there must be ways of applying it. Most of the Qur'anic legislations are revealed in general principles so that the specific methods on how to apply them depend on the circumstances at that time. These general principles can also be regarded as the shari' $a h$ values which are open for interpretations depending on the society, constitutional legal framework and other related issues that exist in any given community.

In applying the law and in the execution of punishments, authorities must resort to hikmah, literally wisdom, philosophy and rationale underlying a particular law. It means taking into consideration the wisdom and philosophy behind the framing of a law. Thus, the law for traffic light may be considered Islamic as the hikmah behind such a law is avoiding vehicle and pedestrian collisions.

Lastly, Muslims need to take into account the concept of rahmah (love, compassion and mercy), which is an all encompassing principle of the Shari'ah. Allah has prescribed for himself the rule of rahmah and the Prophet s.a.w. was sent as "rahmah for the worlds." requires the judges to avert punishment by doubts and to be kind in prescribing punishments. Knowledge of the law is not enough if one does not know how and when to apply and execute the law. One must treat Islamic law and its Sharī'ah rulings as mercy to mankind. To deem

${ }^{71}$ Al Quran, Al-Anbiya, 107. 
the law Islamic, the law must contain principles of goodwill and benevolence to mankind.

\section{CONCLUSION}

The discussion and debate surrounding the issue of whether a law can be considered Islamic or not must be seen from a wider angle rather than narrowing down to legal rulings. To be considered Islamic, a law may not necessarily be derived directly from the sources of Islamic law i.e., Holy Qur'an and Sunnah. A law can still be considered Islamic if it encapsulates the wider message of Islam. Any attempt to limit Islamic law to just what is derived directly from the sources must be reconsidered in order to avoid making Islamic law irrelevant and unable to adapt to the ever-changing world. In enacting a law, it is essential to rely upon Islamic sources but the law must also adhere to the principles of equality before the law, justice, the protection against persecution and maqassid alshari' 'ah. It is equally important to be cognisant of the principle of morality and to resort to hikmah and rahmah.

Laws enacted in many most countries like Malaysia may not incorporate specific verses from the Holy Qur'an and the Sunnah. What is needed is to analyse the substance of the law in order to determine if the law is in line with the spirit of Islam and if it is applied freely without fear or favour. The spirit or essence of the law must always prevail over the forms of the law. Careful analysis of the meaning of the provisions in the given Act must be made before a law can be considered Islamic or otherwise. The law must be of benefit to humankind regardless whether Muslim or non-Muslim. Most of the laws enacted in Malaysia may be considered to be of benefit to mankind. Most, certainly not, all laws conform to the requirements of being considered Islamic.

Islam is al-din that encompasses the whole of people's affairs. This does not imply that Islam dictates everything to the people up to the minute details. The philosophy behind $t a$ 'zir whereby those in authority are given wide discretion to enact laws that accommodate the needs of their people should be embraced to fully comprehend the meaning of Islam as al-din, a complete and comprehensive way of life. This, ipso facto, warrants not to confine Islamic law to the three pillars of Islamic criminal law namely hudūd, qisas and ta 'zirr. Islamic law is more than just these three pillars. 
As Allah says in the Qur'an:

"O you who have believe, be persistently standing firm in justice, witnesses for Allah, even if it be against yourselves or parents and relatives. Whether one is rich or poor, Allah is more worthy of both. So follow not [personal] inclination, lest you not be just. And if you distort [your testimony] or refuse [to give it], then indeed Allah is ever, with what you do, Acquainted."

${ }^{72}$ Al Qur'an, Al-Nisa, 4:135. 